\begin{abstract}
A ntonio Molina Flores (Orce 1958) es poeta y profesor de estética por vocación. Pone pasión en lo que hace, pero esa pasión no le devora, sino la vuelca hacia fuera y la contagia con entusiasmo. En este orden de cosas, es una de las almas de la iniciativa poética Cuadernos de Roldán de Sevilla que, alérgica a cualquier pretenciosidad, congrega a gentes de toda ralea y profesión en torno a la poesía y el ingenio, unas cervecitas fresquitas y vinos de solera en las tascas de la Alameda de Hércules. Así, la bibliografía de los Cuadernos comprende una selecta muestra de los mejores bares de España y parte del extranjero, además de otra prueba de las profundas raíces populares de la poesía en esta tierra.
\end{abstract}

Pero Molina Flores conoce y vive toda la poesia. Y hace mucho tiempo, el romanticismo alemán tocó sus fibras y él sintió el eco de aquella lejana selva negra centroeuropea, aquellos cantos a la locura y la belleza.

El título del poema que nos regala hace alusión a un seudónimo con el que el poeta suabo firmaba sus obras cuando, ya al final de su vida y cegado por la luz de la locura, montaba en cólera cada vez que oía hablar de un tal Johann Christian Friedrich Hölderlin. El último verso-colofón es una frase más o menos textual citada por algunos de sus biógrafos: Una princesa rusa llena de admiración le había regalado un piano - que él no sabía tocar -, y a su pregunta de cómo pudiera devolverle el magnífico favor, la princesa le pidió un poema. $Y$ he aqui su contestación. C.E.

\title{
ANTONIO MOLINA FLORES - POESÍA DEL GUADALNECKAR
}

\section{FRIEDRICH HÖLDERLIN DECIDE LLAMARSE SCARDANELLI}

Qué locura seguir con la razón como único argumento para entender la vida

Vuelvo sereno a la naturaleza y antes que la palabra de los sabios quiero oír el silencio de los necios

$Y$ en las riberas del Neckar olvidarme del nombre, del cuerpo,

del pasado

¿Ha dicho Usted que quería un poema? ¿Sobre

qué, sobre la primavera? ¿O tal vez sobre el espíritu del tiempo?

\section{FRIEDRICH HÖLDERLIN BESCHLIEBT SCARDANELLI ZU HEIBEN}

Welch ein Wahnsinn noch immer mit dem Verstand als einzigem Argument

das Leben zu verstehen zu wollen.

Gelassen kehre ich zurück zur Natur und viel lieber als das Wort der Weisen mag ich das Schweigen der Narren hörn

\section{Und an den Ufern des Neckars Den Namen, Den Körper; \\ Die Vergangenheit vergessen}

¿Sie sagten Sie wollten ein Gedicht? ¿Über was, über den Frühling? ¿Oder vielleicht über den Geist der Zeit?

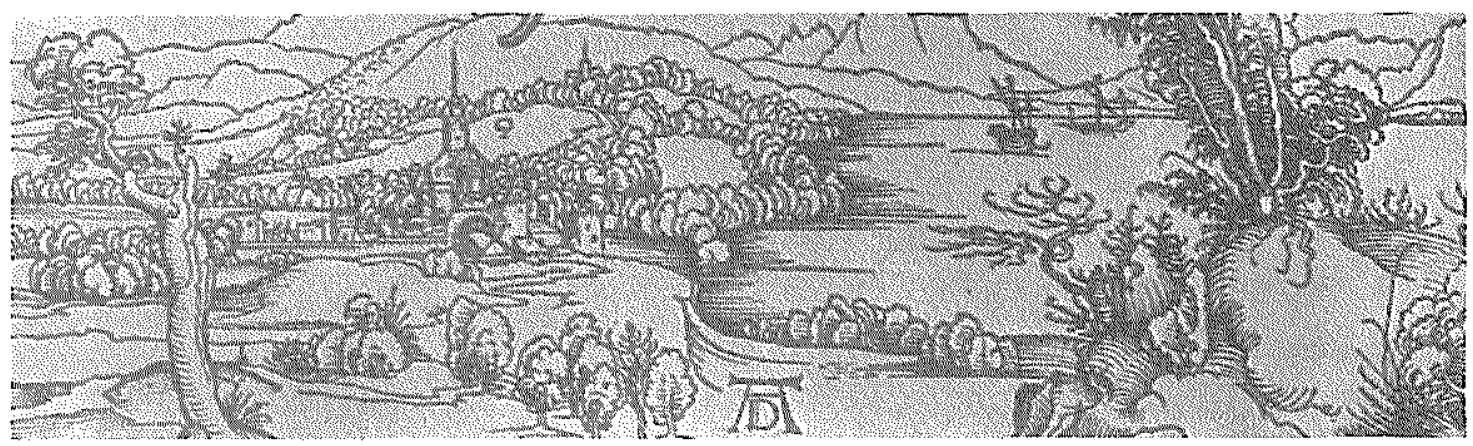

